Original Research Article

\title{
Journey of Indian Mathematics from Vedic Era
}

Handa, Nidhi

Department of Mathematics, Gurukul Kangri Vishwavidyalya, Haridwar, Uttarakhand, India

Corresponding Author: nidhi_6744@yahoo.com

\section{A R T I C L E I N F O}

Received: 28 January 2018 | Accepted: 30 April 2018 | Published Online: 15 August 2018

DOI: $10.31786 / 09756272.18 .9 .1 .127$

EOI: 10.11208/essence.18.9.1.127

Article is an Open Access Publication.

This work is licensed under Attribution-Non Commercial 4.0 International

(https://creativecommons.org/licenses/by/4.0/)

(C)The Authors (2018). Publishing Rights @ MANU_ICMANU \& ESSENCE_IJERC.

\section{A B S T R A C T}

The paper points out how initially proposed theories by European scholars of Mathematics, considering algebra and geometry of Greek and / or Old-Babylonian origin came to be discarded as studies expanded to Vedic works like Shatpath Brahamana and Taittiriya Samhita.

\section{K E Y W O R D S}

Indian Mathematics | Vedic Era | Ancient mathematics

\section{I T A T I O N}

Handa, Nidhi (2018): Journey of Indian Mathematics from Vedic Era. ESSENCE Int. J. Env. Rehab. Conserv. IX (1): 217-221. 


\section{Introduction}

Existence of Mathematics before Christ may be referred as foundation of Mathematics.

1. Mathematics In Vedas (8000 B. C.) Mathematics in Indus Valley Civilization (8000-3000B.C.)

2. Pingala and Panini'S (2850 B.C.)

3. Sulbasūtras (1000-500 B.C.)

4. Jain Mathematics (500-100 B.C.)

The current scholarly outlook can rightly be called scientific. Therefore contemporary intellectuals have quite some interest in the history of mathematics and science.

*"For some, the failure to acknowledge the success of non-Western cultures derives not just from ignorance, but from a conspiracy."

*Dick Teresi- Lost Discoveries, Simon \& Schuster, 2002: $\mathrm{Pp}-11$

The importance of the creation of zero mark can never be exaggerated. This giving to airy nothing, not merely a local habitation and a name, a picture, a symbol, but helpful power, is the characteristic of the Hindu race, whence it sprang. It is like coining the nirvana into dynamos. No single mathematical creation has been more potent for the general on-go of intelligence and power.

G. B. Halsted: On the Foundation and Technique of Mathematics

It also brings out some references of Indian mathematicians spending time in China in eighth century and using Indian mathematics there for calendrical purposes. Further, though it is universally accepted that the present number system, called Hindu Numerals' originated in India. However, there is a lot of speculation as when and where did the so called 'Hindu Numerals' first came to be recorded and used in Indian works. Going to the very roots, presenting direct internal evidence from
Vedas, the paper presents the following points:

1. The numbers $1,2,3, \ldots 9$, with 9 as the largest single digit find mention in the 'richaas' and mantras of the Vedas;

2. There is enough evidence that a method to denote 'zero' was known to Vedic seers.

3. The Vedas refer to what in the modern terminology are called 'sequences of numbers';

4. That the idea of fractions, both unit and others, has also been found clear mention in Vedas.

\section{Theories of Origin of Mathematics in Greece and Babylonia}

The European renaissance of $1300-1600$ traced roots of everything to Ionian Greece, in particular to sixth century BC. Following these lines, WWR Hall in 1901 wrote, "The history of Mathematics cannot with certainty be traced back to any school or period before that of Ionian Greeks." In these early years of European intellectual growth, contributions of India were obviously not considered. After Sanskrit studies attracted some European scholars, this situation was changed. In 1875 G. Thibaut, a Sanskrit scholar with a view to inform the learned world about Indian mathematics, translated a large part of

\section{'Sulvasutras.'}

In 1877 Cantor realizing the importance of Thibaut's work, began a comparative study of Greek and Indian mathematics. Initially he concluded that Indian geometry is derived from Alexandrian knowledge. However, some 25 years later, with greater study, he concluded that the Indian geometry and Greek geometry are related. The process of assigning dates were also picked up. Later Cantor eventually conceded a much earlier date to Indian geometry. 
In 1928 Neugebauer, published a paper in which he traced that the so called Pythagoras theorem was known well over a thousand years before Pythagoras, but in 1937 made a hazard guess of geometry being of Babylonian origin.

Seidenberg (1978) expanded the study of Vedic sources, including 'Shatpath Brahmana' and 'Taittiriya Samhita' closely comparing 'Greek and Vedic Mathematics' as well as 'Old - Babylonian and Vedic Mathematics, concluded as follows:

"... geometric algebra existed in India before the classical period of Greece."

"A comparison of Pythagorean and Vedic mathematics together with some chronological considerations showed ... [that] a common source for Pythagorean and Vedic mathematics is to be sought either in Vedic mathematics or in an older mathematics much like it. The view that Vedic mathematics is a derivative of Old-Babylonian [is] rejected."

\section{Indian Mathematicians in China}

Another interesting study has been brought out by Nobel Laureate Amartya Sen (The Argumentative Indian, 2005). In a chapter on 'China and India', he mentions, "Several Indian mathematicians and astronomers held positions in China's scientific establishment, and an Indian scientist, Gautam Siddhartha (Qutan Xida, in Chinese) even became the president of the official Board of Astronomy in China in the eighth century."

\{Here one story of Parshuramji\} seems to refer to the knowledge of the value of PIE (p). It also refers to the curiosity for the value of PIE. In other words, it lets us think that there has a tradition of mutual adjustment of diśa, ksetra and pinda.

SLOKA त्रिः सप्तकृत्व पृथिवीं कृत्वा निः क्षत्रियां प्रभुः। समन्तप. न्चके चक्रे शोणितोदान हृदान् नृप।। (भाग० ६कृ९६कृ९६)
“Out of revenge of Parshuram's father's death, Parshuram attacked 21 times (to end the seed of ऐएजतपलं) on ोएजतपलं and made five ponds full of their blood"

After following the simple processes shown in the śloka, we come to know

1 कृत्वा निः क्षत्रियां - कृत्वा ;कवपदहद्धय नि कपजीवनजद्धयख्क्ष(शून्य, -मतवद्ध, त्रियां ;३ए ६एधद्ध means leaving 0,3,6,9

2. समन्त पंचक \& even numbers $(2,4,8)$. After writing, 5 , at the end of $2,4,8$, we get the numbers

3. चक्रे प्रभुः - By following cyclic process and mutually changing ( $\left(\begin{array}{llllll}1 & 4 & 2 \backslash 8 & 5 & 7\end{array}\right) 2$ and 4 get the sum one by one of first three numbers with last three numbers so that $(1+8,4+5,7+2=9)$

4. त्रिः सप्त कृत्वः \& Apply 3 to the beginning and 7 to the end 3.142857 is got.

In this way, we see that the above stated ślo$\mathrm{ka}$, we get the number which led to the general value of the proportion of the circumference and diameter of the circle.

According to R. D. Singh knowledge of science is imparted in secret way, though they knew that this would help mankind in development of society.

Sen further writes: "Calendrical studies, in which Indian astronomers located in China in the eighth century, ... were particularly involved, made good use of the progress of trigonometry that had already occurred in India by then (going much beyond the original Greek roots of Indian trigonometry). The movement east of Indian trigonometry to China was part of a global exchange of ideas that also went west around that time. Indeed this was also about the time when Indian trigonometry was having a major impact on the Arab world (with widely used Arabic translations of the works of Aryabhata, Varahamihira, Brahmagupta and others) which would 
later influence European mathematics as well, through the Arabs."

Sen points out, "Gautam (Qutan Xida) produced the great Chinese compendium of astronomy Kaiyvan Zhanjing - an eighthcentury scientific classic. He was also engaged in adopting a number of Indian astronomical works into Chinese. For example, Jiuzhi li, which draws on a particular planetary calendar in India ('Navagraha calendar') is clearly based on the classical Panchsiddhantika, produced around $550 \mathrm{CE}$ by Varahamihira. It is mainly an algorithmic guide to computation, estimating such things as the duration of eclipses based on the diameter of the moon and other relevant parameters. The techniques involved drew on methods that were established by Aryabhata and then further developed by his followers inIndia such as Varahamihira and Brahmagupta."

\section{Number Evidence Directly from Vedas:}

The famous dictum of RgVeda, 'ekam sad vipra bahuda vadanti' uses 'ekam' meaning 'one' as the cardinal number. Further to search numbers in Vedas, let us refer to the the famous and fundamental stanza 'purush — sukta' — of RgVeda.

\section{Śulba Sūtras}

'Śulba' means 'rope' and 'Sūtras' means 'formula'. Thus 'Sulva sutra' literally means

'formulas of measurements' which basically means 'geometry'. Their origin can be traced

to Vedas and scholars consider that these must have been known are least eight centuries B.C. The ideas presented therein seem to be motivated by considerations of forming yajna alters. Śulba Sūtras contains what is called Pythagoras theorem, but not the proof. Two main Sulbsūtra are that of Baudhayana and of Apastambha. Baudhayana lived around
800 BC and Apastambha 600 BC. Apastambha improved and expanded on the rules given by Baudhayana.

\section{Some other major names in the history of Hindu Mathematics}

Aryabhata 1 is a major name in world history of mathematics. According to internal evidence he was born in 476 and died in the year 550. His Aryabhatiya is available. It provides summary of Hindu mathematics known in his time covering topics on arithmetic, algebra, plane trigonometry, continued fractions, quadratic equations, sums of power series and a table of sines.

Varahamihir is practically the most famous astrologer that we have known. Delhi's adjoining area Mehrouli is named after him. He was born in 505 and died in 587. He worked at Ujjain which had been an important center for mathematics since around $400 \mathrm{AD}$.

1. Brahmgupt(598-670)

2. Bhaskara $1(600-680)$

3. Lalla(720-790)

4. Sridhara (Eighth century)

5. Govinda-Svami $(800-860)$

6. Mahavira (800-870)

7. Prathudaka-Swami $(830-890)$

8. Sankara (840-900)

9. Aryabhata II (920-1000)

10. Vijayanandi $(940-1010)$

11. Sripati (1019-1066)

12. Brahma Deva (1060-1130)

13. Bhaskara II (1114-1185)

14. Mahendra Suri (1340-1410)

15. Narayana $(1340-1400)$

16. Madhava (1350-1425)

17. Nilakantha (1444-1544)

18. Jyesthadeva $(1500-1575)$

19. Kamalakara (1616-1700)

20. Jagannath $(1690-1750)$

21. Srinivasa Ramanujan (1887-1920) 


\section{References}

Sen, A. (2005): The Argumentative Indian, Penguin Books.

Amma T. A. Saraswati (1979): Geometry in Ancient and Medival India, Motilal Banarsidas, Delhi

Rai, R. (1976 ): Aryabhatta: Aryabhatiya, Editor:Indian National Science Academy, New Delhi,

Atharva Veda (1975): Dayanand Sansthan , New Delhi,

Boyer, C. B. (1989): A History of Mathematics, (Revised by Uta C. Maerzbach). John Wiley \& sons, New York.

Cajori, F. (1958): History of Mathematics, 2nd revised and Enlarged edition, New York,

Cantor, M. (1977): Cantor, M.: Grakoindische Studien, Zeit. Fur Math, u., Physik, 22.

Datta, B. (1932): (2) TheScience of Śulba , a study in early Hindu geometry, Calcutta University.

Dick, T. (2002): Lost Discoveries, Simon \& Schuster,

Hall, WWR (1901): A Short History of Mathematics, London,.

Handa, N. and Taneja, P. (2010): Enlargement of Vedis in Sulbasūtrās,Indian Jourl. Of History of Science, 45.2,175-188.

Menninger, K. (1969): — Number Words and Number Symbols: A Cultural History of Numbers; (English Translation frtom original German, by Paul Broneer), MIT Press, Cambridge, .RgVeda (Two Parts) (1975): Dayanand Sansthan, New Delhi.

Seidenberg, A. (1978): The Origin of Mathematics, Archive for History of Exact Sciences, $18,301-342$
Thibout, G. (1875): 'On the Sulbasutra,'Journal of Asiatic Society of Bengal,44 pt.I,No 3,227-275 .

YajurVeda (1975): Dayanand Sansthan, New Delhi.

Yajur Veda-Samhita (1973): Edited by Mahrishi Devrat, Banaras Hindu Uni. Shodh Prakashan. 